\title{
PENGARUH BEBAN KERJA INDIVIDU, BEBAN KERJA \\ ORGANISASI, DAN KEPEMIMPINAN TERHADAP \\ KINERJA KARYAWAN (Studi Kasus Bank Sinarmas Klaten)
}

\author{
Retno Tri Vulandari \\ Program Studi Sistem Informasi, STMIK Sinar Nusantara Surakarta \\ retno.tv@gmail.com
}

\begin{abstract}
ABSTRAK
Dunia perbankan merupakan dunia kerja yang memiliki beban yang besar, beban kerja bukan hanya ditimbulkan oleh individu tetapi juga dari organisasi serta pemimpin. Beban kerja yang semakin tinggi akan mempengaruhi kinerja masing-masing karyawan. Oleh karena itu dalam penelitian ini akan dilakukan analisa pengaruh beban kerja individu, organisasi, dan kepemimpinan terhadap kinerja karyawan. Penelitian ini bertujuan untuk mengetahui seberapa besar pengaruh beban kerja terhadap kinerja karyawan, seberapa besar pengaruh kebijakan organisasi terhadap kinerja karyawan, seberapa besar pengaruh sikap kepemimpinan terhadap kinerja karyawan, dan seberapa besar ketiganya mempengaruhi kinerja karyawan. Subjek penelitian ini adalah 60 karyawan Bank Sinar Mas wilayah Klaten. Hasil penelitian sebesar 76,2\% kinerja karyawan dipengaruhi oleh beban kerja individu, beban kerja organisasi, dan kepemimpinan.
\end{abstract}

Kata kunci: Analisa Pengaruh; Regresi Linier Ganda.

\section{PENDAHULUAN}

Persaingan dan tuntutan profesionalitas yang semakin tinggi menimbulkan banyaknya tekanan yang harus dihadapi dalam lingkungan kerja. Tekanan yang berasal dari lingkungan kerja, lingkungan keluarga dan lingkungan sosial berpotensial menimbulkan kecemasan. Tekanan mempunyai dampak positif dan negatif. Dampak positif pada tingkat rendah sampai pada tingkat menengah bersifat fungsional dalam arti berperan sebagai pendorong peningkatan kinerja karyawan. Sedangkan pada dampak negatif tingkat tinggi adalah penurunan pada kinerja karyawan yang drastis (Sasono, 2004)

Beban kerja diakibatkan karena kondisi kelelahan fisik, emosional dan mental. Proses berlangsung secara bertahap, akumulatif, dan lama kelamaan menjadi semakin memburuk. Dalam jangka pendek, beban yang dibiarkan begitu saja tanpa penanganan yang serius dari pihak perusahaan membuat karyawan menjadi tertekan, tidak termotivasi, dan frustasi menyebabkan karyawan bekerja tidak optimal sehingga kinerjanya pun akan terganggu. Dalam jangka panjang, karyawan tidak dapat menahan beban kerja maka ia tidak mampu lagi bekerja di 
perusahaan. Pada tahap yang semakin parah, beban bisa membuat karyawan menjadi sakit atau bahkan akan mengundurkan diri.

Sebagai manusia biasa, karyawan pada tentunya dihadapkan dengan kondisi dilematis. Di satu sisi mereka harus bekerja untuk fokus pada visi perusahaan yaitu memberi kepuasan bagi pelanggan sementara di sisi lain mereka memiliki kebutuhan dan keinginan yang perlu mendapat perhatian dari perusahaan. Kondisi ini tentu akan menimbulkan beban kerja.

Oleh sebab itu penting bagi perusahaan, untuk memenuhi kebutuhan karyawan dan menciptakan kenyamanan. Beban pekerjaan dapat diartikan sebagai tekanan yang dirasakan karyawan karena tugas-tugas pekerjaan tidak dapat terpenuhi. Artinya, beban muncul saat karyawan tidak mampu memenuhi apa yang menjadi tuntutan pekerjaan.

Kepemimpinan adalah kegiatan atau seni mempengaruhi orang lain agar dapat bekerjasama yang didasarkan pada kemampuan orang tersebut untuk membimbing orang lain dalam mencapai tujuan-tujuan yang diinginkan kelompok. Kepemimpinan juga memiliki pengaruh terhadap kinerja baik bersifat positif maupun negatif, gaya kepemimpinan yang menekankan pencapaian target misalnya, ada sebagian karyawan yang termotivasi dengan target yang dibebankan maka hal ini bisa menunjang kinerja karyawan, namun sebagian karyawan justru merasa terbeban dan kinerjanya justru akan menurun.

Berdasarkan uraian di atas, maka akan dilakukan penelitian pengaruh beban kerja individu, beban kerja organisasi, dan kepemimpinan terhadap kinerja karyawan pada Bank Sinarmas Klaten.

\section{METODE PENELITIAN}

Untuk memperoleh data yang dibutuhkan dalam penelitian ini, peneliti melakukan penelitian pada PT. Bank Sinarmas Klaten.

Pengumpulan data penelitian ini menggunakan metode sebagai berikut :

1. Kuesioner yaitu teknik pengumpulan data dengan menggunakan dan memberikan daftar pertanyaan yang telah disiapkan kemudian dibagikan kepada setiap responden untuk diisi dan dijawab. 


\section{Retno Tri Vulandari}

Kuesioner terdiri dari empat kuesiner yaitu:

a. Kuesioner beban kerja individu yang terdiri atas tujuh pertanyaan.

Berikut penjabaran masing-masing pertanyaan:

Pertanyaan 1 : Berisi tentang Pencapaian prestasi individu.

Pertanyaan 2 : Berisi tentang Dukungan keluarga.

Pertanyaan 3 : Berisi tentang Keinginan pindah kerja.

Pertanyaan 4 : Berisi tentang Apresiasi perusahaan.

Pertanyaan 5 : Berisi tentang Kenyamanan kerja.

Pertanyaan 6 : Berisi tentang Pencapaian harapan individu.

Pertanyaan 7 : Berisi tentang Peningkatan prestasi kerja.

b. Kuesioner beban kerja organisasi terdiri atas delapan pertanyaan.

Berikut penjambaran masing-masing pertanyaan:

Pertanyaan 1 : Berisi tentang Diskriminasi Pembagian Kerja.

Pertanyaan 2 : Berisi tentang Gaji yang Kurang Mencukupi.

Pertanyaan 3 : Berisi tentang Keterbatasan Partisipasi Kerja.

Pertanyaan 4 : Berisi tentang Ancaman PHK.

Pertanyaan 5 : Berisi tentang Persaingan Kerja.

Pertanyaan 6 : Berisi tentang Hubungan antar Organisasi.

Pertanyaan 7 : Berisi tentang Suasana Kerja.

Pertanyaan 8 : Berisi tentang Lingkungan Kerja.

c. Kuesioner kepemimpinan terdiri atas enam pertanyaan.

Berikut penjambaran masing-masing pertanyaan:

Pertanyaan 1:Berisi tentang Hubungan antar Atasan dan Karyawan.

Pertanyaan 2 : Berisi tentang Perbedaan Kepentingan.

Pertanyaan 3 : Berisi tentang Tekanan Peraturan.

Pertanyaan 4 : Berisi tentang Buruknya Koordinasi Pekerjaan

Pertanyaan 5 : Berisi tentang Ketidakjelasan Perintah Atasan

Pertanyaan 6 : Berisi tentang Minimnya fasilitas.

d. Kuesioner beban kinerja terdiri atas lima pertanyaan.

Berikut penjabaran masing-masing perytanyaan:

Pertanyaan 1 : Berisi tentang Buruknya Kinerja.

Pertanyaan 2 : Berisi tentang Kurangya Semangat Kerja 


$$
\begin{aligned}
& \text { Pertanyaan } 3 \text { : Berisi tentang Kurangnya Konsentrasi } \\
& \text { Pertanyaan } 4 \text { : Berisi tentang Tinginya Tingkat Emosional } \\
& \text { Pertanyaan } 5 \text { : Berisi tentang kurangnya Loyalitas Kerja. }
\end{aligned}
$$

2. Wawancara, yaitu data yang diperoleh dengan mengadakan wawancara langsung dengan kepala HRD Bank Sinarmas (Persero) Tbk Kantor Wilayah X Klaten

3. Dokumentasi yaitu teknik pengumpulan data yang digunakan untuk mendapatkan data mengenai keadaan Bank Sinarmas (Persero) Tbk Kantor Wilayah X Klaten secara umum, keadaan beban kinerja karyawan.

Metode analisis data untuk membuktikan hipotesis yang telah dikemukakan, maka dalam penelitian ini digunakan dua macam metode analisis, yaitu :

a. Analisis Deskriptif : analisis deskriptif kuantitatif yang menggambarkan secara umum tentang beban kerja dan kinerja karyawan.

b. Analisis Kuantitatif : metode analisis yang digunakan dengan cara mengumpulkan data, dan menyatakan variabel-variabel yang menggambarkan persepsi karyawan terhadap beban kerja serta kinerja karyawan dalam kategori yang pada akhirnya akan menjadi total skor dari pengisian kuesioner oleh responden. Pengisian kuesioner diukur dengan menggunakan skala Likert dengan lima poin. Adapun skor yang diberikan pada setiap jawaban responden, adalah :
a. Sangat Setuju (SS) dengan bobot 5
b. Setuju (S) diberi bobot 4
c. Kurang Setuju (KS) diberi bobot 3
d. Tidak Setuju (TR) diberi bobot 2
e. Sangat Tidak Setuju (STS) diberi bobot 1

Analisis Regresi Linear Berganda untuk menghitung besarnya pengaruh secara kuantitatif dari perubahan kejadian (Variabel Y) dipengaruhi oleh variabel bebas $\mathrm{X}_{1}, \mathrm{X}_{2}$ sehingga rumus umum dari regresi linear berganda ini adalah :

$$
Y=a+b_{1} X_{1}+b_{2} X_{2}+b_{3} X_{3}
$$

dengan

Y : Variabel dependen yaitu Kinerja Karyawan 


\section{Retno Tri Vulandari}

$\mathrm{X}_{1}$ : Variabel Independen yaitu Beban Individu

$\mathrm{X}_{2}$ : Variabel Independen yaitu Beban Organisasi

$\mathrm{X}_{3}$ : Variabel Independen yaitu Kepemimpinan

a : Nilai konstanta

b : Koefisien arah regresi

Uji koefisien korelasi analisis determinasi dalam regresi linear berganda digunakan untuk mengetahui prosentase sumbangan pengaruh variabel independen $\left(\mathrm{X}_{1}, \mathrm{X}_{2}, \ldots \ldots \mathrm{X}_{\mathrm{n}}\right)$ secara serentak terhadap variabel dependen $(\mathrm{Y})$. Koefisien ini menunjukkan seberapa besar prosentase variasi variabel independen yang digunakan dalam model mampu menjelaskan variasi variabel dependen. R2sama dengan 0, maka tidak ada sedikitpun prosentase sumbangan pengaruh yang diberikan variabel independen terhadap variabel dependen, atau variasi variabel independen yang digunakan dalam model tidak menjelaskan sedikitpun variasi variabel dependen. Sebaliknya $\mathrm{R}^{2}$ sama dengan 1 , maka prosentase sumbangan pengaruh yang diberikan variabel independen terhadap variabel dependen adalah sempurna, atau variasi variabel independen yang digunakan dalam model menjelaskan $100 \%$ variasi variabel dependen.

Koefisien determinasi $\left(\mathrm{R}^{2}\right)$ pada intinya mengukur seberapa jauh kemampuan model dalam menerangkan variasi variabel dependennya. Nilai koefisien determinasi $\left(\mathrm{R}^{2}\right)$ yang mendekati satu berarti variabel-variabel independennya menjelaskan hampir semua informasi yang dibutuhkan untuk memprediksi variable dependen (Ghozali, 2009).

Uji $\mathrm{t}$ untuk mengetahui apakah hubungan antara variabel bebas mempunyai pengaruh yang nyata atau tidak terhadap variabel terikat, maka dilakukan uji hipotesis. Bentuk pengujiannya adalah sebagai berikut :

$\mathrm{H}_{0}: \mathrm{r}=0$; artinya tidak terdapat pengaruh yang signifikan antara variabel predikator $\left(\mathrm{X}_{\mathrm{i}}\right)$ dengan variabel terikat $\left(\mathrm{Y}_{\mathrm{i}}\right) . \mathrm{H}_{\mathrm{A}}: \mathrm{r} \neq 0$; artinya ada pengaruh yang signifikan antara variabel predikator $\left(\mathrm{X}_{1}\right)$ dengan variabel terikat.

Selanjutnya untuk mengetahui signifikansi kontanta dari setiap variabel independen terhadap variabel terikat.

$$
t=\frac{r \sqrt{n-2}}{\sqrt{1-r^{2}}}
$$


dengan

$\mathrm{t} \quad$ : nilai t yang dihitung selanjutnya disebut t-hitung

r : koefisien korelasi

n : jumlah Sampel

Definisi Operasional untuk memudahkan arah penelitian ini, definisi operasional penelitian ini adalah sebagai berikut :

1. Variabel Terkait (Kinerja (Y))

Variabel terkait (dependent variable) adalah suatu variabel yang dikenai pengaruh oleh variabel lain dan dalam notasinya ditulis dengan Y. Variabel terkait dalam penelitian ini adalah Kinerja Karyawan PT Bank Sinarmas Klaten. Kinerja merupakan hasil kerja yang dicapai oleh seseorang menurut ukuran yang berlaku untuk pekerjaan yang bersangkutan

2. Variabel Bebas

Variabel bebas (Independent variable) adalah variabel yang fungsinya mempengaruhi variabel lainnya. Variabel bebas dalam penelitian ini adalah Beban Kerja. Beban Kerja adalah suatu tanggapan adaktif, ditengahi oleh perdebatan individual atau proses psikologis, yaitu suatu konsekuensi dari setiap kegiatan (lingkungan), situasi, atau kejadian eksternal yang membebani tuntutan psikologis atau fisik yang berlebihan terhadap seseorang (Gibson,2007).

Secara umum beban kerja dikelompokkan menjadi beban individu dan beban organisasi, yaitu:

Beban Individu $\left(\mathrm{X}_{1}\right)$ meliputi sikap, karakteristik, sifat-sifat fisik, minat dan motivasi, pengalaman, umur, jenis kelamin, pendidikan, serta faktor individu lainnya.

Beban Organisasi (X2) meliputi faktor fisik dan pekerjaan, terdiri dari metode kerja, kondisi dan desain perlengkapan kerja, penataan ruang dan lingkungan fisik (penyinaran, temperature, dan fentilasi). Faktor sosial dan organisasi, meliputi peraturan-peraturan organisasi, sifat organisasi, jenis latihan dan pengawasan, sistem upah dan lingkungan sosial.

Kepemimpinan (X3), dari kata pimpin mengandung aspek bimbingan, memimpin :berarti membimbing, menunjukkan jalan. Memimpin berati 


\section{Retno Tri Vulandari}

membimbing, menunjukkan jalan. Dengan demikian proses memimpin itu ada proses agar yang dipimpin mngikuti petunjuk dari yang membimbingnya/yang memimpinnya. Dalam hal ini seseorang yang memimpin berarti ada upaya untuk mempengaruhi perilaku yang dipimpin. Jadi, dalam kondisi dan situasi bagaimanapun, jika seseorang berusaha untuk untuk mempengaruhi perilaku orang lain, maka aktivitas semacam itu merupakan aktivitas kepemimpinan.

Dalam penelitian ini beban kerja karyawan dilihat dari jawaban kuesioner dari para karyawan PT. Bank Sinarmas wilayah Klaten.

\section{HASIL PENELITIAN DAN PEMBAHASAN}

\section{Uji Validitas tiap Item Pertanyaan untuk Variabel Beban Individu $\left(\mathbf{X}_{1}\right)$}

Tabel 1. Validitas Variabel Beban Kerja Individu

\begin{tabular}{|c|c|c|c|c|c|}
\hline & & $\begin{array}{l}\text { apresiasi } \\
\text { perusahaan }\end{array}$ & $\begin{array}{l}\text { bosan } \\
\text { pekerjaan }\end{array}$ & $\begin{array}{c}\text { putus } \\
\text { asa }\end{array}$ & $\begin{array}{l}\text { beban } \\
\text { individu }\end{array}$ \\
\hline \multirow{3}{*}{$\begin{array}{l}\text { tidak ada apresiasi } \\
\text { perusahaan }\end{array}$} & Pearson Correlation & 1 & -.041 & .159 & .574 \\
\hline & Sig. (2-tailed) & & .756 & .226 & .000 \\
\hline & $\mathrm{N}$ & 60 & 60 & 60 & 60 \\
\hline \multirow[t]{3}{*}{ bosan pekerjaan } & Pearson Correlation & -.041 & 1 & $.338^{* 1}$ & $.708^{*}$ \\
\hline & Sig. (2-tailed) & .756 & & .008 & .000 \\
\hline & $\mathrm{N}$ & 60 & 60 & 60 & 60 \\
\hline \multirow[t]{3}{*}{ putus asa } & Pearson Correlation & .159 & $.338^{* *}$ & 1 & $.683^{* \prime}$ \\
\hline & Sig. (2-tailed) & .226 & .008 & & .000 \\
\hline & $\mathrm{N}$ & 60 & 60 & 60 & 60 \\
\hline \multirow[t]{3}{*}{ beban individu } & Pearson Correlation & $.574^{\mathrm{N}}$ & $.708^{* x}$ & $.683^{\mathrm{x}}$ & 1 \\
\hline & Sig. (2-tailed) & .000 & .000 & .000 & \\
\hline & $\mathrm{N}$ & 60 & 60 & 60 & 60 \\
\hline
\end{tabular}

Berdasarkan data tersebut pada Tabel di atas,dengan melihat nilai Pearson Correlation antara pertanyaan tidak ada apresiasi perusahaan $\left(\mathrm{p}_{1}\right)$ dengan beban individu $\left(\mathrm{X}_{1}\right)$, pertanyaan bosan pekerjaan $\left(\mathrm{p}_{2}\right)$ dengan beban individu $\left(\mathrm{X}_{1}\right)$, dan pertanyaan putus asa $\left(\mathrm{p}_{3}\right)$ dengan beban individu $\left(\mathrm{X}_{1}\right)$ berada pada tarafsignifikansi korelasi sebesar 0,01 (lihat tanda bintang) dan nilai sig. (2tailed) $=0,000<0,01$ maka dapat dinyatakan bahwa item-item pertanyaan untuk Variabel beban individu $\left(\mathrm{X}_{1}\right)$ dinyatakan valid. Semua data pada pertanyaan tersebut dapat digunakan untuk olah data berikutnya. 


\section{Uji Validitas tiap Item Pertanyaan untuk Variabel Beban Organisasi $\left(\mathbf{X}_{2}\right)$}

Tabel 2. Validitas Variabel Beban Kerja Organisasi

\begin{tabular}{|c|c|c|c|c|c|}
\hline & & $\begin{array}{l}\text { sistem } \\
\text { gaji }\end{array}$ & $\begin{array}{c}\text { suasana } \\
\text { kantor }\end{array}$ & $\begin{array}{c}\text { lingkungan } \\
\text { kerja }\end{array}$ & $\begin{array}{c}\text { beban } \\
\text { organisasi }\end{array}$ \\
\hline \multirow[t]{3}{*}{ sistem gaji } & Pearson Correlation & 1 & .033 & -.029 & $.531^{* \prime}$ \\
\hline & Sig. (2-tailed) & & .801 & .823 & .000 \\
\hline & $\mathrm{N}$ & 60 & 60 & 60 & 60 \\
\hline \multirow[t]{3}{*}{ suasana kantor } & Pearson Correlation & .033 & 1 & .086 & $.601^{* \prime}$ \\
\hline & Sig. (2-tailed) & .801 & & .514 & .000 \\
\hline & $\mathrm{N}$ & 60 & 60 & 60 & 60 \\
\hline \multirow[t]{3}{*}{ lingkungan kerja } & Pearson Correlation & -.029 & .086 & 1 & $.647^{*}$ \\
\hline & Sig. (2-tailed) & .823 & .514 & & .000 \\
\hline & $\mathrm{N}$ & 60 & 60 & 60 & 60 \\
\hline \multirow[t]{3}{*}{ beban organisasi } & Pearson Correlation & $.531^{* *}$ & $.601^{*}$ & $.647^{* *}$ & 1 \\
\hline & Sig. (2-tailed) & .000 & .000 & .000 & \\
\hline & $\mathrm{N}$ & 60 & 60 & 60 & 60 \\
\hline
\end{tabular}

Berdasarkan data tersebut pada Tabel di atas,dengan melihat nilai Pearson Correlation antara pertanyaan system gaji $\left(\mathrm{p}_{4}\right)$ dengan beban organisasi $\left(\mathrm{X}_{2}\right)$, pertanyaan suasana kantor $\left(\mathrm{p}_{5}\right)$ dengan beban organisasi $\left(\mathrm{X}_{2}\right)$, dan pertanyaan lingkungan kerja $\left(\mathrm{p}_{6}\right)$ dengan beban organisasi $\left(\mathrm{X}_{2}\right)$ berada pada tarafsignifikansi korelasi sebesar 0,01 (lihat tanda bintang) dan nilai sig. (2-tailed) $=0,000<$ 0,01 maka dapat dinyatakan bahwa item-item pertanyaan untuk Variabel beban organisasi $\left(\mathrm{X}_{2}\right)$ dinyatakan valid. Semua data pada pertanyaan tersebut dapat digunakan untuk olah data berikutnya.

\section{Uji Validitas tiap Item Pertanyaan untuk Variabel Kepemimpinan $\left(\mathbf{X}_{3}\right)$}

Tabel 3. Validitas Variabel Kepemimpinan

\begin{tabular}{|ll|r|r|r|r|}
\hline & $\begin{array}{c}\text { hubungan atasan } \\
\text { dan bawahan }\end{array}$ & $\begin{array}{c}\text { peraturan } \\
\text { yang berat }\end{array}$ & $\begin{array}{c}\text { atasan yang } \\
\text { menuntut }\end{array}$ & $\begin{array}{c}\text { beban } \\
\text { kepemimpinan }\end{array}$ \\
\hline $\begin{array}{l}\text { hubungan } \\
\text { atasan dan } \\
\text { bawahan }\end{array}$ & Pearson Correlation & 1 & .013 & .076 & .560 \\
& $\mathrm{~N}$ & & .920 & .566 & .000 \\
peraturan & Pearson Correlation & 60 & 60 & 60 & 60 \\
yang berat & Sig. (2-tailed) & .013 & 1 & .112 & .594 \\
& $\mathrm{~N}$ & .920 & & .395 & .000 \\
& Pearson Correlation & 60 & 60 & 60 & 60 \\
\hline atasan yang & .076 & .112 & 1 & .687 \\
menuntut & Sig. (2-tailed) & .566 & .395 & & .000 \\
& $\mathrm{~N}$ & 60 & 60 & 60 & 60 \\
\hline beban & Pearson Correlation & .560 & .594 & .687 & 1 \\
kepemimpina & Sig. (2-tailed) & .000 & .000 & .000 & 60 \\
& $\mathrm{~N}$ & 60 & 60 & 60 & \\
\hline
\end{tabular}




\section{Retno Tri Vulandari}

Berdasarkan data tersebut pada Tabel di atas, dengan melihat nilai Pearson Correlation antara pertanyaan hubungan atasan dan bawahan $\left(\mathrm{p}_{7}\right)$ dengan beban kepemimpinan $\left(\mathrm{X}_{3}\right)$, pertanyaan peraturan yang berat $\left(\mathrm{p}_{8}\right)$ denganbeban kepemimpinan $\left(\mathrm{X}_{3}\right)$, dan pertanyaan atasan yang menuntut $\left(\mathrm{p}_{9}\right)$ dengan beban kepemimpinan $\left(\mathrm{X}_{3}\right)$ berada pada tarafsignifikansi korelasi sebesar 0,01 (lihat tanda bintang) dan nilai sig. (2-tailed) $=0,000<0,01$ maka dapat dinyatakan bahwa item-item pertanyaan untuk Variabel beban kepemimpinan $\left(\mathrm{X}_{3}\right)$ dinyatakan valid. Semua data pada pertanyaan tersebut dapat digunakan untuk olah data berikutnya.

\section{Uji Validitas tiap Item Pertanyaan untuk Variabel Kinerja (Y)}

Tabel 4. Validitas Variabel Kinerja

\begin{tabular}{|ll|r|r|r|r|}
\hline & \multicolumn{1}{|c|}{$\begin{array}{c}\text { malas } \\
\text { bekerja }\end{array}$} & $\begin{array}{c}\text { mudah emosi } \\
\text { dalam bekerja }\end{array}$ & $\begin{array}{c}\text { kesalahan } \\
\text { kerja }\end{array}$ & Kinerja \\
\hline malas bekerja & Pearson Correlation & 1 & -.030 & .122 & .653 \\
& Sig. (2-tailed) & & .822 & .354 & .000 \\
& $\mathrm{~N}$ & 60 & 60 & 60 & 60 \\
\hline mudah emosi & Pearson Correlation & -.030 & 1 & -.267 & .512 \\
dalam bekerja & Sig. (2-tailed) & .822 & & .039 & .000 \\
& $\mathrm{~N}$ & 60 & 60 & 60 & 60 \\
\hline kesalahan kerja & Pearson Correlation & .122 & -.267 & 1 & .448 \\
& Sig. (2-tailed) & .354 & .039 & & .000 \\
& $\mathrm{~N}$ & 60 & 60 & 60 & 60 \\
\hline Kinerja & Pearson Correlation & .653 & .512 & .448 & 1 \\
& Sig. (2-tailed) & .000 & .000 & .000 & 60 \\
& $\mathrm{~N}$ & 60 & 60 & 60 & 60 \\
\hline
\end{tabular}

Berdasarkan data tersebut pada Tabel di atas,dengan melihat nilai Pearson Correlation antara pertanyaan malas kerja $\left(\mathrm{p}_{10}\right)$ dengan Kinerja $(\mathrm{Y})$, pertanyaan mudah emosi dalam bekerja $\left(\mathrm{p}_{11}\right)$ denganKinerja $(\mathrm{Y})$, dan pertanyaan kesalahan kerja $\left(\mathrm{p}_{12}\right)$ dengan Kinerja $(\mathrm{Y})$ berada pada tarafsignifikansi korelasi sebesar 0,01 (lihat tanda bintang) dan nilai sig. (2-tailed) $=0,000<0,01$ maka dapat dinyatakan bahwa item-item pertanyaan untuk Variabel Kinerja (Y) dinyatakan valid. Semua data pada pertanyaan tersebut dapat digunakan untuk olah data berikutnya.

\section{Uji Reliabilitas Variabel Beban Kerja Individu $\left(\mathbf{X}_{1}\right)$}


Nilai Cronbach's Alpha sebesar 0,734 sehingga item pertanyaan untuk mendapatkan nilai Variabel $\mathrm{X}_{1}$ dapat dikatakan andal. Hal ini berdasarkan kriteria indeks reliabilitas pada table 5 .

Tabel 5. Kriteria Indeks Reliabilitas

\begin{tabular}{|l|l|l|}
\hline No & \multicolumn{1}{|c|}{ Interval } & \multicolumn{1}{c|}{ Kriteria } \\
\hline 1 & $<0,200$ & Sangat rendah \\
\hline 2 & $0,200-0,399$ & Rendah \\
\hline 3 & $0,400-0,599$ & Cukup \\
\hline 4 & $0,600-0,799$ & Tinggi \\
\hline 5 & $0,800-1,000$ & Sangat Tinggi \\
\hline
\end{tabular}

\section{Uji Reliabilitas Variabel Beban Kerja Organisasi $\left(\mathbf{X}_{2}\right)$}

Nilai Cronbach's Alpha sebesar 0,685 sehingga item pertanyaan untuk mendapatkan nilai Variabel $\mathrm{X}_{2}$ dapat dikatakan andal. Hal ini berdasarkan kriteria indeks reliabilitas pada table 5 .

\section{Uji Reliabilitas Variabel Kepemimpinan $\left(\mathbf{X}_{3}\right)$}

Nilai Cronbach's Alpha sebesar 0,707 sehingga item pertanyaan untuk mendapatkan nilai Variabel $\mathrm{X}_{2}$ dapat dikatakan andal. Hal ini berdasarkan kriteria indeks reliabilitas pada table 5 .

\section{Uji Reliabilitas Variabel Kinerja (Y)}

Nilai Cronbach's Alpha sebesar 0,753 sehingga item pertanyaan untuk mendapatkan nilai Variabel $\mathrm{X}_{2}$ dapat dikatakan andal. Hal ini berdasarkan kriteria indeks reliabilitas pada table 5 .

\section{Persamaan Regresi Ganda}

Suatu analisis yang bertujuan untuk mengetahui pengaruh suatu variabel terhadap variabel lain. Dalam analisis regresi, variabel yang mempengaruhi disebut Independent Variable (variabel bebas) dan variabel yang dipengaruhi disebut Dependent Variable (variabel terikat). Dalam persamaan regresi hanya terdapat satu variabel bebas dan satu variabel terikat, maka disebut sebagai persamaan regresi sederhana, sedangkan jika variabel bebasnya lebih dari satu, maka disebut sebagai persamaan regresi berganda.

Tabel 6. Koefien Model Regresi

\begin{tabular}{|l|c|c|c|c|c|c|c|}
\hline \multirow{4}{*}{ Model } & \multicolumn{2}{|c|}{$\begin{array}{c}\text { Unstandardized } \\
\text { Coefficients }\end{array}$} & $\begin{array}{c}\text { Standardized } \\
\text { Coefficients }\end{array}$ & \multirow{2}{*}{$\mathrm{t}$} & & \multicolumn{2}{|c|}{ Collinearity Statistics } \\
\cline { 2 - 3 } \cline { 7 - 8 } & $\mathrm{B}$ & Std. Error & Beta & $\mathrm{t}$ & Tolerance & VIF \\
\hline
\end{tabular}




\section{Retno Tri Vulandari}

\begin{tabular}{|c|c|c|c|c|c|c|c|c|}
\hline \multirow[t]{4}{*}{1} & (Constant) & -.040 & 1.780 & & -.023 & .982 & & \\
\hline & beban individu & .306 & .083 & .371 & 3.683 & .001 & .990 & 1.010 \\
\hline & beban organisasi & .339 & .096 & .355 & 3.523 & .001 & .990 & 1.010 \\
\hline & kepemimpinan & .382 & .100 & .387 & 3.834 & .000 & .989 & 1.011 \\
\hline
\end{tabular}

Berdasarkan hasil pengolahan data analisis regresi linier pada Tabel 6, persamaan regresi yang dibentuk adalah : $\mathrm{Y}=-0,040+0,306 \mathrm{X}_{1}+0,339 \mathrm{X}_{2}+$ $0,382 \mathrm{X}_{3}$. Persamaan regresi linier tersebut memberikan gambaran bahwa:

a. Variabel Beban Individu $\left(\mathrm{X}_{1}\right)$ mempunyai nilai koefisien regresi sebesar 0,306 yang berarti Beban Individu mempunyai pengaruh positif terhadap Kinerja (Y), yaitu jika terjadi kenaikan beban individu maka akan menurunkan kinerja;

b. Variabel Beban Organisasi $\left(\mathrm{X}_{2}\right)$ mempunyai nilai koefisien regresi sebesar 0,339 yang berarti beban organisasi mempunyai pengaruh positif terhadap kinerja (Y), yaitu jika terjadi kenaikan beban organisasi maka akan menurunkan kinerja;

c. Variabel Kepemimpinan $\left(\mathrm{X}_{3}\right)$ mempunyai nilai koefisien regresi sebesar 0,382 yang berarti kepemimpinan mempunyai pengaruh positif terhadap kinerja (Y), yaitu jika terjadi kenaikan kepemimpinan maka akan menurunkan kinerja;

d. Konstanta mempunyai nilai $-0,040$ yang artinya jika variabel $\mathrm{X}_{1}, \mathrm{X}_{2}$, dan $\mathrm{X}_{3}$ dalam mempunyai nilai nol atau tidak ada maka kinerja sebesar -0,040 dan nilai tersebut merupakan pengaruh dari variabel lain yang tidak dimasukkan dalam model regresi linier atau tergabung dalam variabel penggangu (e).

Nilai koefisien regresi dan model regresi linier tersebut belum dapat digunakan, baik sebagai alat pengambilan keputusan maupun alat peramalan, sebelum dilakukan uji hipotesis.

\section{Uji Hipotesis Parsial (Uji T)}

Hipotesis penelitian yang diajukan adalah Kinerja (Y) dipengaruhi oleh Variabel Beban Individu $\left(\mathrm{X}_{1}\right)$, Beban Organisasi $\left(\mathrm{X}_{2}\right)$, dan Kepemimpinan $\left(\mathrm{X}_{3}\right)$. Nilai $\mathrm{T}$ tabel untuk data sebanyak 60 responden, jumlah variabel sebanyak 4 variabel, dan tingkat signifikan yang digunakan 5\% adalah sebesar $\pm 2,001717$ (lihat Tabel T students pada df: 58 dan $\alpha$ : 2,5\%). Daerah penolakannya adalah jika nilai $\mathrm{t}<-2,001717$ atau $\mathrm{t}>2,001717$. 
Berdasarkan tabel 6, nilai T hitung untuk variabel beban individu sebesar 3,683 (Sig.0,001), variabel beban organisasi sebesar 3,523 (Sig.0,001), dan variabel kepemimpinan sebesar 3,834 (Sig. 0,000). Nilai T hitung untuk masingmasing variabel independen tersebut berada pada daerah penolakan Ho atau mempunyai nilai Sig. di bawah 0,05 (5\%). Dengan demikian dapat disimpulkan bahwa masing-masing variabel Independen mempunyai pengaruh yang signifikan terhadap variabel Dependen, atau variabel beban individu, beban organisasi, dan kepemimpinan secara parsial mempunyai pengaruh yang signifikan terhadap variabel penurunan kinerja karyawan.

\section{Uji Hipotesis Serampak (Uji F)}

Untuk melakukan uji hipotesis secara serempak (Uji F) hipotesis statistik yang diajukan adalah: Ho $: \mathrm{b} 1=\mathrm{b} 2=\mathrm{b} 3=0$ dan $\mathrm{Ha}: \mathrm{b} 1 \neq \mathrm{b} 2 \neq \mathrm{b} 3 \neq 0$

Tabel 7. Uji Anova

\begin{tabular}{|l|r|r|r|c|c|}
\hline Model & Sum of Squares & Df & Mean Square & F & Sig. \\
\hline 1 Regression & 42.271 & 3 & 14.090 & 14.435 & $.000^{a}$ \\
Residual & 54.663 & 56 & .976 & & \\
Total & 96.933 & 59 & & & \\
\hline
\end{tabular}
a. Predictors: (Constant), kepemimpinan, beban organisasi, beban individu
b. Dependent Variable: kinerja

Nilai $\mathrm{F}$ tabel dengan df:3;58 dan tingkat signifikan $(\alpha)$ 5\% adalah sebesar 2,180727. Sedangkan untuk nilai F hitung berdasarkan tabel 7 adalah sebesar 14,435. Dengan membandingkan nilai $\mathrm{F}$ hitung dengan $\mathrm{F}$ tabel, diketahui bahwa F hitung lebih besar dari F tabel atau 14,435 > 2,180727, maka dapat disimpulkan bahwa variabel beban individu, beban organisasi, dan kepemimpinan secara keseluruhan mempunyai pengaruh yang signifikan terhadap variabel penurunan kinerja karyawan.

\section{Koefisien Determinasi dan Korelasi}

Berdasarkan tabel 8, nilai koefisien determinasi atau $\mathrm{R}^{2}$ dari hasil pengolahan data adalah sebesar 0,762 atau $76,2 \%$. Nilai tersebut memberikan gambaran bahwa sumbangan variabel independen (variabel beban kerja individu, beban kerja organisasi, dan kepemimpinan) terhadap variabel Dependen (variabel kinerja karyawan) adalah sebesar 76,2\% dan sisanya sebesar 23,8\% merupakan 


\section{Retno Tri Vulandari}

sumbangan variabel-variabel lain yang tidak dimasukkan dalam model dan tergabung dalam variabel pengganggu (e) dalam model regresi linier.

Tabel 8. Koefisien Determinasi Model Regresi

\begin{tabular}{|l|r|r|r|r|r|}
\hline Model & $\mathrm{R}$ & $\mathrm{R}$ Square & $\begin{array}{c}\text { Adjusted } \\
\text { R Square }\end{array}$ & $\begin{array}{c}\text { Std. Error of the } \\
\text { Estimate }\end{array}$ & Durbin-Watson \\
\hline 1 & $.873^{\mathrm{a}}$ & .762. & .762 & .988 & 2.037 \\
\hline
\end{tabular}
a. Predictors: (Constant), stress kepemimpinan, stress organisasi, stress individu
b. Dependent Variable: kinerja

Nilai korelasi berganda (R) dari hasil pengolahan data adalah sebesar $87,3 \%$. Nilai korelasi tersebut menggambarkan bahwa hubungan antara variabel independen dengan variabel dependen adalah mempunyai hubungan yang erat atau hubungan antara variabel beban kerja individu, beban kerja organisasi, dan kepemimpinan dengan variabel kinerja karyawan adalah mempunyai hubungan yang erat. Standard error of the estimate adalah suatu ukuran banyaknya kesalahan model regresi dalam memprediksikan nilai Y. Dari hasil regresi diperoleh nilai 0,988 , hal ini berarti banyaknya kesalahan dalam prediksi variabel kinerja karyawan sebesar 0,988. Sebagai pedoman jika Standard error of the estimate kurang dari standar deviasi $\mathrm{Y}$, maka model regresi semakin baik dalam memprediksi nilai $\mathrm{Y}$.

\section{Asumsi Klasik Analisis Regresi}

Uji asumsi klasik dilakukan untuk mengetahui apakah model estimasi telah memenuhi kriteria ekonometrika, dalam arti tidak terjadi penyimpangan yang cukup serius dari asumsi-asumsi yang harus dipenuhi dalam metode Ordinary Least Square (OLS). Terdapat tiga asumsi yang diperlukan dalam penaksiran OLS, yaitu:

1. Tidak adanya Autokorelasi antar gangguan (e);

2. Tidak adanya Multikolinearitas;

3. Variansi kesalahan pengganggu tetap atau homoskedastisitas (tidak terjadi Heteroskedastisitas); dan

4. Normalitas antar gangguan (e).

\section{Uji Autokorelasi}

Uji Autokorelasi digunakan untuk menguji apakah dalam sebuah model regresi linier terdapat korelasi antara kesalahan pengganggu pada periode $t$ dengan 
kesalahan pada periode $\mathrm{t}$ - 1(sebelumnya). Untuk menguji Autokorelasi dapat dilihat dari nilai Durbin Waston (DW), yaitu

- jika nilai DW terletak antara dudan $(4-\mathrm{dU})$ atau du $\leq \mathrm{DW} \leq(4-\mathrm{dU})$ berarti bebas dariAutokorelasi, sebaliknya

- jika nilai DW < dLatau DW > $(4-\mathrm{dL})$ berarti terdapat Autokorelasi.

- Nilai dL dan dU dapat dilihat pada tabel Durbin Waston, yaitu nilai dL ; $\mathrm{dU} ; \alpha ; \mathrm{n} ;(\mathrm{k}-1)$. Keterangan: $\mathrm{n}$ adalah jumlah sampel, $\mathrm{k}$ adalah jumlah variabel, dan $\alpha$ adalah taraf signifikan.

Nilai tabel Durbin Watson pada $\alpha=5 \% ; \mathrm{n}=60 ; \mathrm{k}-1=3$ adalah $\mathrm{dL}=$ 1,480 dan $\mathrm{dU}=1,689$. Hasil pengolahan data pada Tabel 8 , menunjukkan nilai Durbin Watson sebesar 2,037 dan nilai tersebut berada di antara dU dan (4 $\mathrm{dU}$ ) atau 1,689 $<2,037<2,311$ maka dapat disimpulkan bahwa dalam regresi linier tersebut tidak terdapat Autokorelasi atau tidak terjadi korelasi diantara kesalahan pengganggu.

\section{Uji Multikolinearitas}

Uji multikolinearitas digunakan untuk mengetahui apakah terjadi korelasi yang kuat di antara variabel-variabel independen yang diikutsertakan dalam pembentukan model. Untuk mendeteksi apakah model regresi linier mengalami multikolinearitas dapat diperiksa menggunakan Variance Inflation Factor (VIF) untuk masing-masing variabel Independen, yaitu jika suatu variabel independen mempunyai nilai VIF > 10 berarti telah terjadi multikolinearitas.

Berdasarkan Tabel 6 maka diperoleh nilai VIF variabel beban kerja individu $\left(\mathrm{X}_{1}\right)$ adalah 1,010 kurang dari 10 artinya tidak terjadi multikolinearitas pada variable tersebut. Nilai VIF variabel beban kerja organisasi $\left(\mathrm{X}_{2}\right)$ adalah 1,010 kurang dari 10 artinya tidak terjadi multikolinearitas pada variabel tersebut. Nilai VIF variabel kepemimpinan $\left(\mathrm{X}_{3}\right)$ adalah 1,011 kurang dari 10 artinya tidak terjadi multikolinearitas pada variabel tersebut.

\section{Uji Heteroskedastisitas}

Uji heteroskedastisitas digunakan untuk menguji apakah dalam model regresi linier kesalahan pengganggu (e) mempunyai variansi yang sama atau tidak dari satu pengamatan ke pengamatan yang lain. Untuk menguji Heteroskedastisitas dapat diketahui dari nilai signifikan korelasi Rank Spearman 


\section{Retno Tri Vulandari}

antara masing-masing variabel independen dengan residualnya. Jika nilai signifikan lebih besar dari $\alpha(5 \%)$ maka tidak terdapat heteroskedastisitas, dan sebaliknya jika lebih kecil dari $\alpha(5 \%)$ maka terdapat heteroskedastisitas.

Tabel 9. Heteroskedastisitas Model

\begin{tabular}{|ll|r|r|r|r|}
\hline & & $\begin{array}{c}\text { Beban kerja } \\
\text { individu }\end{array}$ & $\begin{array}{c}\text { Beban kerja } \\
\text { organisasi }\end{array}$ & kepemimpinan & residual \\
\hline $\begin{array}{llr}\text { Beban } \\
\text { kerja } \\
\text { individu }\end{array}$ & Correlation Coefficient & 1.000 & -.028 & .067 & .040 \\
& Sig. (2-tailed) &. & .832 & .609 & .759 \\
& $\mathrm{~N}$ & 60 & 60 & 60 & 60 \\
\hline Beban & Correlation Coefficient & -.028 & 1.000 & .042 & -.031 \\
kerja & Sig. (2-tailed) & .832 & .747 & .815 \\
organisasi & $\mathrm{N}$ & 60 & 60 & 60 & 60 \\
\hline & $\mathrm{N}$ & .067 & .042 & 1.000 & -.113 \\
kepemimpi & Correlation Coefficient & .609 & .747 &. & .389 \\
nan & Sig. (2-tailed) & 60 & 60 & 60 & 60 \\
& $\mathrm{~N}$ & .040 & -.031 & -.113 & 1.000 \\
\hline Residual & Correlation Coefficient & .759 & .815 & .389 &. \\
& Sig. (2-tailed) & 60 & 60 & 60 & 60 \\
\hline
\end{tabular}

Berdasarkan Tabel 9 tersebut di atas, pada kolom residual dapat dilihat bahwa nilai Correlation Coefficient adalah rendah atau nilai signifikan masingmasing variabel independen di atas 5\%, artinya masing-masing variabel independen tidak mempunyai hubungan dengan residualnya. Dengan demikian, dapat disimpulkan bahwa tidak terdapat heteroskedastisitas.

\section{Asumsi Normalitas Residual}

Uji normalitas bertujuan untuk menguji apakah dalam model regresi, variabel pengganggu atau residual memiliki distribusi tidak normal. Kalau asumsi ini dilanggar maka uji statistik menjadi tidak valid untuk jumlah sampel kecil (Ghozali, 2006). Berdasarkan Gambar 1 maka asumsi normalitas residual terpenuhi. Persamaan regresi berganda $Y=-0,040+0,306 X_{1}+0,339 X_{2}+0,382$ $\mathrm{X}_{3}$ dapat digunakan untuk peramalan variabel kinerja karyawan jika diketahui variabel beban kerja individu, beban kerja organisasi, dan kepemimpinan

Gambar 1. Regression Standardized Residual 


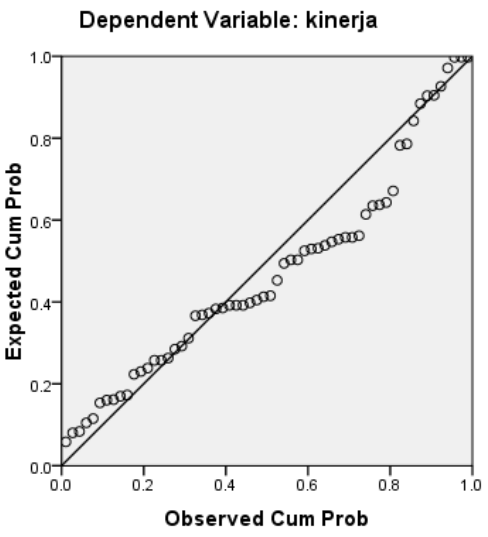

\section{SIMPULAN}

Berdasarkan hasil pengolahan data persamaan regresi yang dibentuk adalah : $Y=-0,040+0,306 X_{1}+0,339 X_{2}+0,382 X_{3}$. Persamaan regresi linier tersebut memberikan gambaran bahwa: variabel beban kerja individu $\left(\mathrm{X}_{1}\right)$ mempunyai nilai koefisien regresi sebesar 0,306 yang berarti beban kerja individu mempunyai pengaruh positif terhadap kinerja karyawan (Y), yaitu jika terjadi kenaikan beban individu maka akan menurunkan kinerja; variabel organisasi $\left(\mathrm{X}_{2}\right)$ mempunyai nilai koefisien regresi sebesar 0,339 yang berarti beban organisasi mempunyai pengaruh positif terhadap kinerja (Y), yaitu jika terjadi kenaikan beban organisasi maka akan menurunkan kinerja; variabel kepemimpinan $\left(\mathrm{X}_{3}\right)$ mempunyai nilai koefisien regresi sebesar 0,382 yang berarti kepemimpinan mempunyai pengaruh positif terhadap kinerja (Y), yaitu jika terjadi kenaikan kepemimpinan maka akan menurunkan kinerja; konstanta mempunyai nilai 0,040 yang artinya jika variabel $X_{1}, X_{2}$, dan $X_{3}$ dalam mempunyai nilai nol atau tidak ada maka kinerja sebesar -0,040 dan nilai tersebut merupakan pengaruh dari variabel lain yang tidak dimasukkan dalam model regresi linier atau tergabung dalam variabel penggangu (e). Model tersebut dapat digunakan karena memenuhi asumsi klasik normalitas, heteroskedastisitas, multikolinieritas, dan autokorelasi.

\section{DAFTAR PUSTAKA}

Ghozali, I. (2009). Ekonometrika Teori, Konsep, dan Aplikasi dengan SPSS 17. Semarang: Badan Penerbit Universitas Diponegoro.

Gibson, I. (2007). Organisasi: Proses Struktur Perilaku Edisi 5. Jakarta: Erlangga.

Lazarus, Y. (2008). Riset Sumber Daya Manusia. Jakarta: PT Gramedia Pustaka Utama. 
Sasono, E. (2004). Mengelola Beban Kerja. Jurnal Fokus Ekonomi Vol 3 No 2, $134-142$.

Soemalijah, S. (2003). Manajemen Sumber Daya Manusia. Bandung: Alfabeta. Sugiyono. (2005). Statistika untuk Penelitian. Bandung: Alfabeta. 